\title{
Antiosteoporotic effect of Coelatura aegyptiaca shell powder on ovariectomized rats
}

\author{
Amany A. Sayed, Amel M. Soliman*, Sohair R. Fahmy and Mohamed Marzouk \\ Department of zoology, Faculty of Science, Cairo University, Egypt.
}

Accepted 27 August, 2013

\begin{abstract}
The efficacy of Coelatura aegyptiaca shell powder (CES, $500 \mathrm{mg} / \mathrm{kg} \mathrm{BW)} \mathrm{was} \mathrm{evaluated} \mathrm{as} \mathrm{a} \mathrm{calcium}$ supplement in ovariectomized (OVX) rats for ten weeks of treatment. The biochemical components and the antioxidant properties of the shell powder were determined. The bone mineral density (BMD), bone mineral content (BMC), calcium (Ca) and phosphorus $(P)$ contents in serum and bone, serum total alkaline phosphatase (TALP) and bone alkaline phosphatase (BALP), serum calcitonin and parathyroid (PTH) hormones were determined. Furthermore, some of the oxidative stress markers [malondialdehyde (MDA), superoxide dismutase (SOD), glutathione peroxidase (GPx) and total antioxidant capacity (TAC)] were estimated in bone. The current study revealed that CES contained $19.38 \% \mathrm{Ca}, 0.315 \% \mathrm{P}$ as well as some of antioxidant amino acids which have a potent antioxidant activity against 1,1diphenylpicrylhydrazyl (DPPH) free radical. Administration of CES to OVX rats increased BMD, BMC, tibial $\mathrm{Ca}$ and $\mathrm{P}$ contents and BALP activity, as compared to OVX rats. An ameliorative effect was recorded in the levels of calcitonin, PTH, MDA, SOD, GPX and TAC subsequent to CES administration to OVX rats.This ameliorative effect of CES powder against osteoporosis may be attributed to its antioxidant efficacy and/or to its Ca content. In conclusion, CES may have the potential to develop a clinically useful anti-osteoporotic agent, since its effect was comparable with alendronate $(6.5 \mathrm{mg} / \mathrm{kg}$ BW/week).
\end{abstract}

Key words: Ovariectomized rats, Coelatura aegyptiaca shell, calcium supplement, 1,1-diphenylpicrylhydrazyl (DPPH), oxidative stress markers.

\section{INTRODUCTION}

Calcium is the most abundant mineral in the organism and contributes approximately 1 to $2 \%$ to the adult human body weight. A dynamic balance exists between calcium in the extracellular medium and that found in bone, and about $500 \mathrm{mg}$ of this mineral enter and depart daily from the bones (Pérez Llamas et al., 2010). Osteoporosis is the most common skeletal disorder and is considered a risk of fracture (Yalin et al., 2012). It is a systemic metabolic bone disease which presents reduction in bone density together with abnormal structure (Kanis et al., 2008). Osteoporosis may appear in aged men and women due to negative calcium balance (Heaney, 1996). This case may result from a decrease in intestinal calcium absorption, insufficient dietary calcium intake, as well as increased urinary calcium loss associated with estrogen deficiency during menopause (Kaplan and Hirsch, 2004). Dietary risk factors for bone fractures play a special role in the prevention of osteoporosis. Numerous studies indicate that adequate calcium intake improves bone mineral density (Peterlik et al., 2013).

Ovariectomized rats are used specifically as the animal model to observe the effects of osteoporosis since the 
biological mechanisms related with bone resorption in ovariectomized rats highly resemble the post-menopausal bone loss in women (Frost and Jee, 1992). The acute effects of menopause are modeled by ovariectomy which, like natural menopause, stimulates bone resorption by increasing osteoclast formation (Weitzmann and Pacifici, 2006). One important component of the osteoclasts activity is the generation of free radicals which contribute to the process of bone degradation and resorption (Fraser et al., 1996). Ovariectomy alters the generation of reactive oxygen species (ROS) and the antioxidant defense capacity of the cell (Lean et al., 2005), leading to an accumulation of ROS. Furthermore, oxidative stress (OxS) has been linked with osteoporosis (Sánchez-Rodríguez et al., 2007).

It was reported that accumulation of ROS in cellular components is the major factor causing molecular injury which ultimately leads to cell aging and other age-related degenerative diseases (Stagos et al., 2012). Basu et al. (2001) revealed that the osteoporosis could be eliminated when oxidative stress is prevented. Unfortunately, the current pharmacological therapy used for treatment of osteoporosis have serious adverse effects besides its inability to restore lost bone mass (Shirke et al., 2008). Bisphosphonates administration is widely used for management of osteoporosis. However, therapy with bisphosphonates is associated with deleterious effects such as esophageal cancer and osteonecrosis of the jaw (Kuehn, 2009). The predicted increase in the incidence of osteoporosis in women justifies a search for opportunities to prevent bone fractures (Wadolowska et al., 2013). Consequently, there has been a vast increase in the use of natural products that could provide all of the benefits but none of the risks of prescription drugs (Kupferer et al., 2009). Many therapeutic strategies tend to focus on calcium supplements for prevention and treatment of osteoporosis instead of hormone replacement therapy (Wallace et al., 2004; Shaker et al., 2005). Therefore, the present study aims to introduce a new natural calcium source derived from Egyptian freshwater bivalve Coelatura aegyptiaca as an anti-osteoporotic agent. So, the present investigation aims to evaluate the efficacy of C. aegyptiaca shell powder (CES) as a new alternative anti-osteoporotic agent as compared with alendronate, the widely used anti-osteoporotic drug. Furthermore, since osteoporosis positively correlated with OxS, the present study extends to evaluate the antioxidant capacity of the CES powder.

\section{MATERIALS AND METHODS}

\section{Chemicals and reagents}

1,1-diphenyl-1-picrylhydrazyl (DPPH) was purchased from SigmaAldrich (St. Louis, MO, USA). Fosamax (Alendronate) was purchased from Global Napi Pharmaceuticals (New Jersey, USA). Kits of biochemical analyses were purchased from Biodiagnostic Company (Egypt), calcitonin kit was purchased from DRG
International, Inc. (New Jersey, USA) and parathyroid hormone kit was purchased from Immunotech A Beckman Coulter Company (Marseille, France). Any other chemicals were of analytical grade.

\section{Preparation of $C$. aegyptiaca shells (CES) powder}

C. aegyptiaca belong to Unionoidae and are widely distributed along the River Nile from Assiut to Damietta (Moloukhia and Sleem, 2011). Freshwater mussel $C$. aegyptiaca was collected from the Nile River at Giza governorate, Egypt. The meat was removed and the CES was prepared according to $\mathrm{Han}$ et al. (2007). The prepared CES powder was stored in a desiccator to protect it from light and moisture until used.

\section{Determination of shell contents}

For determination of inorganic calcium $(\mathrm{Ca})$ and phosphorus $(\mathrm{P})$ contents, small amounts $(100 \mathrm{mg})$ of prepared CES powder were dissolved in hydrochloric acid. The inorganic $\mathrm{Ca}$ and $\mathrm{P}$ contents of CES powder were determined using biodiagnostic kits. For amino acids determination, the CES powder was analyzed by highperformance liquid chromatography (HPLC); Beckman 6300 amino acid analyzer (Radwan et al., 2007).

\section{In vitro antioxidant assay using DPPH}

The DPPH free radical scavenging assay was carried out for evaluation of antioxidant activity according to the method adopted by Brand et al. (1995). The following concentrations of the CES powder and ascorbic acid (standard reference) were prepared in methanol 10, 20, 30, 40, 50, 60, 70 and $80 \mathrm{mg} / \mathrm{ml}$. Each tube contained $2 \mathrm{ml} \mathrm{DPPH}(0.1 \mathrm{mM}$ in methanol), a certain concentration of CES or ascorbic acid, and the final volume was adjusted to $4 \mathrm{ml}$ with methanol. The solution was shaken and incubated at $37^{\circ} \mathrm{C}$ for $30 \mathrm{~min}$. The control solution (containing DPPH only) underwent the same processes. All measurements were performed in triplicate and methanol was used as a blank. The decrease in absorbance (Abs) was measured at $\lambda=517 \mathrm{~nm}$. The radical scavenging activity was calculated from the following equation:

$\%$ of radical scavenging activity $=\left[\left(\mathrm{Abs}_{\text {control }}-\mathrm{Abs}_{\text {sample }}\right) / \mathrm{Abs}_{\text {control }}\right]$ $\times 100$

\section{Animals}

Adult female Wistar albino rats (Rattus norvegicus) weighing 150 to170 $\mathrm{g}$ were obtained from the animal house of the National Research Center (NRC), Egypt. Rats were housed in polypropylene cages in air-conditioned room at temperature of $20 \pm 2^{\circ} \mathrm{C}$ and under natural day and night cycle. They were fed commercial food pellets and drinking water ad libitum. The rats were kept for a week before the commencement of the study for acclimatization.

\section{Acute toxicity test}

Acute oral toxicity test was done according to the organization for economic cooperation and development (OECD) based on acute oral toxicity up and down procedure 425 guideline (OECD, 2001). Two groups each of five healthy female rats were selected randomly and fasted overnight. The first group was administered, via gavage, CES powder suspension at a limit dose of $5000 \mathrm{mg} / \mathrm{kg}$ body weight. The second group (control group) was given an equal volume of distilled water. All animals were observed at $0,30 \mathrm{~min}, 1$, $2,4,6 \mathrm{~h}$ and thereafter every day for 14 days to check for mortality and abnormal clinical manifestation. The rats were sacrificed after 
14 days and their liver and kidney were excised and fixed in $10 \%$ formalin for $24 \mathrm{~h}$. They were processed and stained with hematoxylin and eosin dyes for histopathological examination. The median effective dose $\left(E D_{50}\right)$ of aforementioned shell powder was selected based on $\mathrm{LD}_{50}$ obtained from acute toxicity study.

\section{Surgical procedure of ovariectomy}

Bilateral ovariectomy was performed. All surgical procedures were performed by the same surgeon for all groups. Following anesthesia with diethyl ether, a $1.5 \mathrm{~cm}$ skin incision was made and the ovaries were removed completely. Thereafter, the ventral muscle and skin were sutured and povidone iodine (betadine) was applied in this area to disinfect the skin (Parhizkar et al., 2008). Finally, the wounded area was powdered with erythromycin (Figure 1A to L).

\section{Experimental design}

Rats were randomly assigned into two main groups, Group I served as sham group that was administered distilled water. The sham rats were anesthetized, laparotomized, and sutured without removing their ovaries (negative control, $\mathrm{n}=14$ ). Group II served as ovariectomized group (OVX, $\mathrm{n}=42$ ). After one week of recovery from surgery, the second group was subdivided into 3 subgroups (14 rats/each subgroup). Subgroup 1 treated with vehicle (distilled water, p.o. daily for 10 weeks). Subgroup 2 treated with CES powder (500 mg/kg BW, p.o. daily for 10 weeks as suspension). Subgroup 3 treated weekly with alendronate, via gavage, as a positive control with a dose of $6.5 \mathrm{mg} / \mathrm{kg} \mathrm{BW} /$ week (Rosenberg et al., 2007). At the end of experiment, one half of the animals $(n=7)$ were sacrificed and blood samples were collected in centrifuge tubes without anti-coagulant, then centrifuged at $3000 \mathrm{rpm}$ for 20 min and the collected sera were stored until use. The two femurs were dissected out and the surrounding tissues were removed. The right femur was frozen for scanning electron microscopy. The left femur was grinded and about $100 \mathrm{mg}$ was taken and homogenized with $2 \mathrm{ml}$ of $0.1 \mathrm{M}$ Tris- $\mathrm{HCl}$ buffer $(\mathrm{pH} 7.2)$. The homogenate was centrifuged at $3000 \mathrm{rpm}$ for $30 \mathrm{~min}$ at $4^{\circ} \mathrm{C}$ and the supernatant was used for biochemical and oxidative stress marker estimations (Ramajayam et al., 2007). All animal procedures were conducted according to the "Guide for the Care and Use of Laboratory Animals" and were approved by the local Cairo University animal research ethics committee.

\section{Measurements of bone mineral content (BMC) and bone mineral density (BMD)}

At the end of experiment, one half of the experimental rats $(n=7)$ were anesthetized and the BMD and BMC of the left tibia were estimated using dual energy X-ray absorptiometry (DEXA, Norland $X$ 46, Version 3.9.6) instrument equipped with dedicated software for small animal measurements (Figure 2). BMC (expressed in grams) was divided by the area of the site that was scanned to obtain BMD (expressed in grams per centimeter squared) (Jo and Choi, 2008).

\section{Determination of tibial calcium and phosphorus contents}

The right tibia was dried overnight at $60^{\circ} \mathrm{C}$ for the determination of dry weight and then ashed at $700^{\circ} \mathrm{C}$ for $14 \mathrm{~h}$. After weighing, the ashes were dissolved in conc. $\mathrm{HCl}$ followed by dilution with deionized water and then used for measurement of calcium and phosphorus levels by a colorimetric method using biodiagnostic kits (Teófilo et al., 2003).

\section{Scanning electron microscopy (SEM)}

The distal part of the right femur was trimmed in a coronal plane. They were treated with $5 \%$ sodium hypochlorite solution (commercial bleach) for $4 \mathrm{~h}$ to expose the epiphyseal and metaphyseal trabecular bone. The bones were then dehydrated in ethanol, dried, mounted on stubs and coated with gold using a sputter coater (Miller and Bowman, 1998). The bones were observed by a JEOL, JSM-5200 scanning electron microscope.

\section{Biochemical analyses}

The appropriate clinical kits (Biodiagnostic, Egypt) were used for the determination of several parameters. Calcium and phosphorus contents in serum and tibial bone were measured according to Gindler and King (1972) and El-Merzabani et al. (1977), respectively. Serum total alkaline phosphatase (TALP) and bone alkaline phosphatase (BALP) were determined colorimetrically according to the method described by Belfield and Goldberg (1971). TALP and BALP were estimated on the day of collection as ALP has a half-life of 1 to 2 days (Swaminathan, 2001). Parathyroid hormone (PTH) was estimated using IRMA PTH kit (A11930, Beckman Coulter Company) and calcitonin was determined by DRG ELISA kit according to Tiegs et al. (1986). Bone supernatants were used for estimation of malondialdehyde (MDA) according to Ohkawa et al. (1979), glutathione peroxidase (GPx) according to Paglia and Valentine (1967), superoxide dismutase (SOD) according to Nishikimi et al. (1972) and total antioxidant capacity (TAC) according to Koracevic et al. (2001).

\section{Statistical analysis}

Statistical analyses were carried out using statistical package for social sciences (SPSS) v.15 software. All data were expressed as means \pm standard error (SE). Data were analyzed by one-way analysis of variance (ANOVA) followed by Duncan post hoc test for comparison between two groups using SPSS software. P valuesof less than 0.05 were considered statistically significant.

\section{RESULTS}

\section{Chemical composition of CES}

The present study revealed that the calcium and phosphorus contents of CES powder were 193.8 and $3.15 \mathrm{mg} / \mathrm{g}$ shell powder, respectively. Table 1 shows that the CES powder containing various amino acids.

\section{DPPH free radical-scavenging activity}

Figure 3 shows that CES powder exhibited a great antioxidant activity where it scavenged above $60 \% \mathrm{DPPH}$ free radical at the lowest concentration $(10 \mathrm{mg} / \mathrm{ml})$. The CES powder exhibited highly antioxidant effect at 70 $\mathrm{mg} / \mathrm{ml}$, at this concentration CES exhibited $85.47 \%$ inhibition in comparison with ascorbic acid (the reference standard) which showed $93.38 \%$ inhibition at the same concentration. 

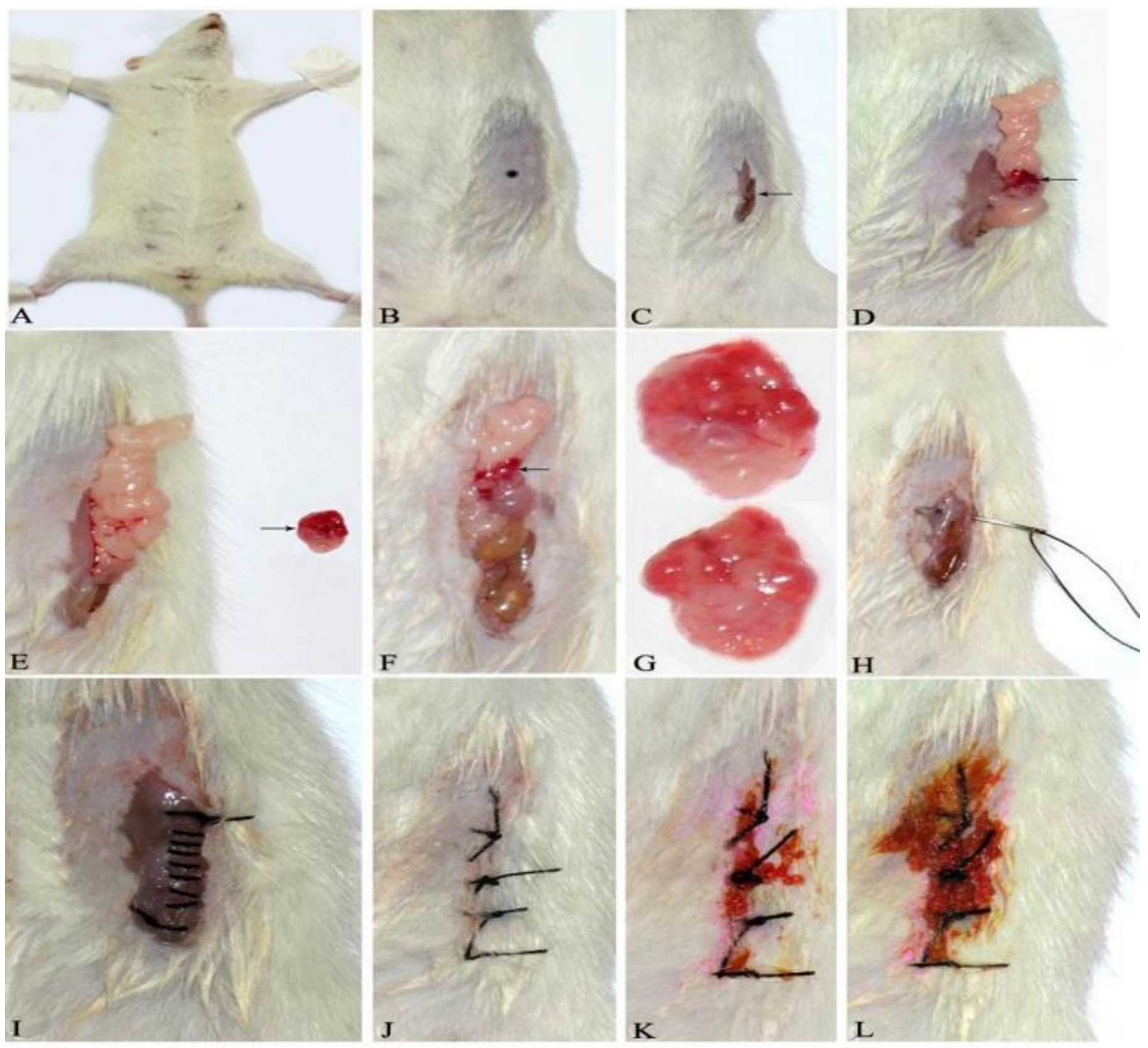

Figure 1. Ovariectomy procedure in rat. (A) Anesthetized rat is laid on operating table from the back. (B) Shaving site indicated by black star. (C) Skin incision point approximately $1.5 \mathrm{~cm}$ is made in the shaving area, indicated by arrow. (D) Ovary and uterine horn are exposed, the ovary was indicated by arrow. (E) The left ovary was removed, indicated by arrow. $(F)$ The right ovary was removed, indicated by arrow. (G) Complete bilateral ovariectomy. (H-L) Muscle, peritoneal cavity and skin were sutured and covered by antiseptic and antibiotic.

\section{Acute toxicity study}

The oral administration of CES powder $(5000 \mathrm{mg} / \mathrm{kg} \mathrm{BW})$ caused neither mortality nor signs of clinical abnormality. At necropsy, no gross pathological observation was found in the target organs as liver and kidney (Figure 4). The $\mathrm{LD}_{50}$ of CES powder was found to be more than $5000 \mathrm{mg} / \mathrm{kg}$ BW and cannot be categorized under the globally harmonized system (GHS) category.

\section{BMD and BMC of the tibia}

The tibial BMC and BMD were decreased significantly $(P$ $<0.05$ ) in the OVX group, as compared to the sham group. Treatment with CES powder $(500 \mathrm{mg} / \mathrm{kg} \mathrm{BW})$ or alendronate $(6.5 \mathrm{mg} / \mathrm{kg} \mathrm{BW} /$ week) significantly alleviated the decreasing effect of ovariectomy on BMD (Table 2). On the other hand, treatment with CES powder or alendronate did not cause any significant difference in 
$\mathrm{L}$ H

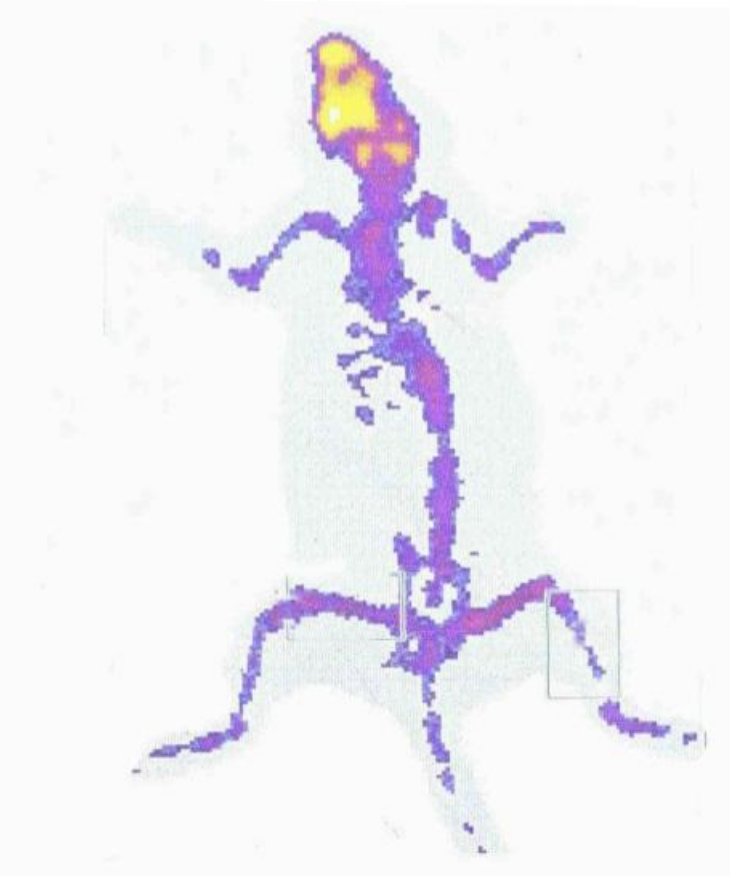

Figure 2. Representative photo showing bone mineral density of tibia by DEXA.

웅 CES Vitamin C

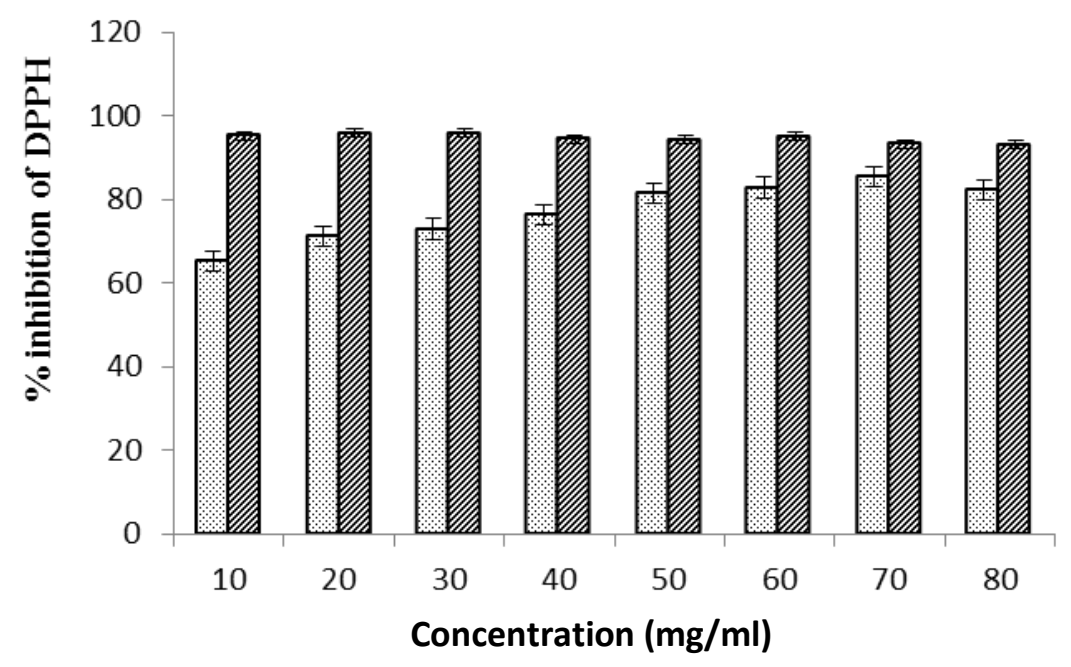

Figure 3. Anti-free radical activity of CES determined by DPPH assay.

BMC value, as compared with OVX group.

\section{Calcium and phosphorus contents}

Ovariectomy was found to cause a significant loss $(\mathrm{P}<$ $0.05)$ in tibial and serum calcium contents when compared to sham group (Table 3). Meanwhile, CES powder supplementation or alendronate treatments were found to help in restoring the tibial calcium level significantly $(\mathrm{P}<$ $0.05)$. On the other hand, a non-significance increase was observed in the levels of serum calciumin CES powder and in alendronate groups (Table 3). Bone and serum phosphorus contents were decreased significantly 


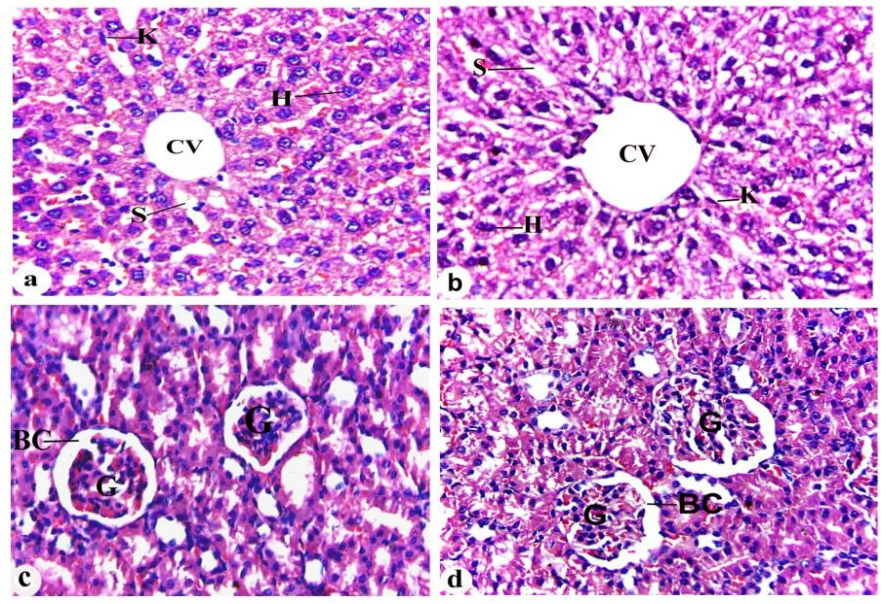

Figure 4. Effect of CES at a limit dose (5000 mg/kg b.wt).

(A) Liver section of the control group showing the normal liver architecture with distinct hepatic cells, sinusoidal spaces, central vein, well preserved cytoplasm and prominent nuclei. (B) No obvious change in liver tissue between control and CES groups was observed. (C) kidney section of the control group showing the normal histological structure of the glomerulus and the Bowman's capsule of Malpighian corpuscles and normal appearance of the tissue. (D) No change was observed in the cortical region of the kidney between the control and CES groups. Bowman's capsule $(B C)$, central vein $(C V)$, glomerulus $(G)$, hepatocyte $(H)$, kupffer cell $(\mathrm{K})$, sinusoid (S) (100×, H\&E).

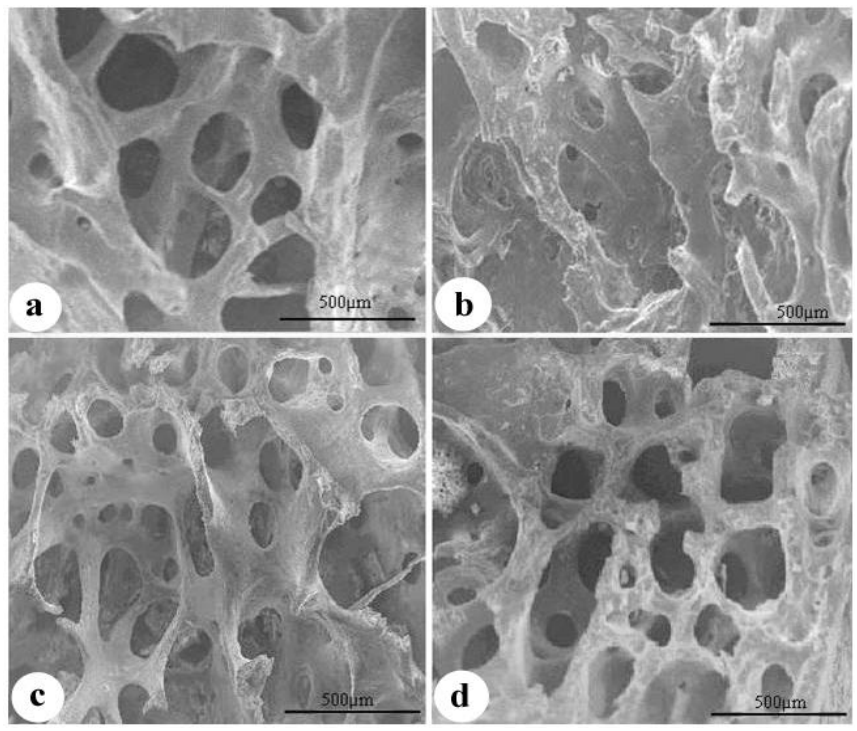

Figure 5. Scanning electron micrographs of the femoral distal metaphyses in rats.

(A) Sham group, (B) OVX group, (C) CES group and (D) Alendronate group. As compared with the OVX group, the trabecular bones of the femoral distal metaphysis reappear in the CES and alendronate groups. Scale bar $=500 \mu \mathrm{m}$.

$(\mathrm{P}<0.05)$ in OVX rats, as compared to sham group. These contents were increased significantly $(P<0.05)$ subsequent to CES powder supplementation, as compared to OVX rats (Table 3). Meanwhile, alendronate
Table 1. Amino acid constituents of CES powder.

\begin{tabular}{lc}
\hline Amino acid & $\mathbf{m g} / \mathbf{g}$ shell powder \\
\hline Cysteine & 0.28298 \\
Glutamic acid & 0.60133 \\
Glycine & 0.72873 \\
Methionine & 0.41405 \\
Alanine & 0.25844 \\
Arginine & 0.25125 \\
Asparagine & 0.18246 \\
Aspartic acid & 0.48985 \\
Glutamine & 0.69051 \\
Histidine & 0.79625 \\
Lysine & 0.40131 \\
Phenylalanine & 0.23824 \\
Isoleucine and leucine & 0.82036 \\
Proline & 0.5217 \\
Serine & 0.95178 \\
Threonine & 0.79533 \\
Tyrosine & 0.888 \\
Valine & 0.512 \\
\hline
\end{tabular}

Table 2. Effect of CES on BMD and BMC of the left tibia of rats.

\begin{tabular}{llc}
\hline Group & BMD $\left(\mathbf{g} / \mathbf{c m}^{2}\right)$ & BMC $(\mathbf{g})$ \\
\hline Sham & $0.112 \pm 0.010^{\mathrm{ac}}$ & $0.289 \pm 0.034^{\mathrm{a}}$ \\
OVX & $0.082 \pm 0.002^{\mathrm{b}}$ & $0.122 \pm 0.007^{\mathrm{b}}$ \\
OVX+CES & $0.102 \pm 0.004^{\mathrm{a}}$ & $0.143 \pm 0.018^{\mathrm{c}}$ \\
OVX+Alendronate & $0.122 \pm 0.002^{\mathrm{c}}$ & $0.112 \pm 0.008^{\mathrm{b}}$ \\
\hline
\end{tabular}

All values are means \pm SE $(n=7)$. Values with different superscript letters are significantly different $(P<0.05)$.

administration caused significant rise $(P<0.05)$ only in serum phosphorus content, as compared to OVX rat group (Table 3).

\section{Scanning electron microscopic analysis}

The connectivity of trabecular bone in the metaphysis exhibited greater connection in sham control group (Figure 5A). However, OVX caused a decrease in femoral trabeculae, appearance of porous and erosive bone as well as disintegration in bone architecture(Figure 5B). CES and alendronate treatments suppressed this decrease and the morphology of the metaphysis remained nearly normal (Figure 5C and D).

\section{Alkaline phosphatase activity}

Statistically, a non-significant difference in serum TALP concentration among the different experimental groups 
Table 3. Effect of CES on calcium (Ca) and phosphorus $(P)$ contents in serum and bone of rats.

\begin{tabular}{lcccc}
\hline Group & $\begin{array}{c}\text { Serum Ca } \\
(\mathbf{m g} / \mathbf{d l})\end{array}$ & $\begin{array}{c}\text { Bone Ca } \\
(\mathbf{m g} / \mathbf{g} \text { ash })\end{array}$ & $\begin{array}{c}\text { Serum P } \\
(\mathbf{m g} / \mathbf{d l})\end{array}$ & $\begin{array}{c}\text { Bone P } \\
(\mathbf{m g} / \mathbf{g} \text { ash })\end{array}$ \\
\hline Sham & $9.894 \pm 0.697^{\mathrm{a}}$ & $84.95 \pm 3.5^{\mathrm{a}}$ & $5.244 \pm 0.258^{\mathrm{a}}$ & $50.3 \pm 2.38^{\mathrm{a}}$ \\
OVX & $5.448 \pm 0.59^{\mathrm{b}}$ & $46.38 \pm 3.12^{\mathrm{b}}$ & $2.8 \pm 0.331^{\mathrm{b}}$ & $33.16 \pm 0.86^{\mathrm{b}}$ \\
OVX+CES & $7.217 \pm 0.697^{\mathrm{c}}$ & $90.4 \pm 2.7^{\mathrm{a}}$ & $4.298 \pm 0.369^{\mathrm{a}}$ & $51.76 \pm 2.85^{\mathrm{a}}$ \\
OVX+Alendronate & $6.815 \pm 0.281^{\mathrm{bc}}$ & $57.64 \pm 1.27^{\mathrm{c}}$ & $4.524 \pm 0.292^{\mathrm{a}}$ & $37.57 \pm 1.84^{\mathrm{b}}$ \\
\hline
\end{tabular}

All values are means $\pm S E(n=7)$. Values with different superscript letters are significantly different $(P<0.05)$.

Table 4. Effect of CES on ALP activity of serum (TALP) and bone (BALP) of rats.

\begin{tabular}{lcc}
\hline Group & $\begin{array}{c}\text { Serum TALP } \\
(\text { IU/L) }\end{array}$ & $\begin{array}{c}\text { BALP } \\
\text { (IU/g protein) }\end{array}$ \\
\hline Sham & $100.315 \pm 7.383$ & $24.9 \pm 2.134^{\mathrm{a}}$ \\
OVX & $120.078 \pm 10.147$ & $6.7 \pm 0.976^{\mathrm{b}}$ \\
OVX+CES & $110.506 \pm 12.628$ & $23.071 \pm 1.755^{\text {ac }}$ \\
OVX+Alendronate & $99.636 \pm 10.293$ & $13.157 \pm 0.967^{\text {bc }}$ \\
\hline
\end{tabular}

All values are means $\pm S E(n=7)$. Values with different superscript letters are significantly different $(P<0.05)$.

Table 5. Effect of CES on serum calcitonin and parathyroid hormone (PTH) levels of rats.

\begin{tabular}{lcc}
\hline Group & Calcitonin $(\mathbf{p g} / \mathrm{ml})$ & PTH $(\mathbf{p g} / \mathbf{m l})$ \\
\hline Sham & $39.327 \pm 1.498^{\mathrm{a}}$ & $25.962 \pm 0.8135^{\mathrm{a}}$ \\
OVX & $32.274 \pm 0.655^{\mathrm{b}}$ & $36.733 \pm 2.0153^{\mathrm{b}}$ \\
OVX+CES & $37.668 \pm 0.516^{\mathrm{ac}}$ & $25.478 \pm 1.271^{\mathrm{a}}$ \\
OVX+Alendronate & $34.782 \pm 1.238^{\mathrm{bc}}$ & $26.869 \pm 0.564^{\mathrm{a}}$ \\
\hline
\end{tabular}

All values are means $\pm S E(n=7)$. Values with different superscript letters are significantly different $(P<0.05)$.

was recorded (Table 4). However, ovariectomy induced a significant decrease $(P<0.05)$ in the BALP activity, as compared to sham rats. CES powder and alendronate treatment increased the BALP activity significantly $(\mathrm{P}<$ 0.05), as compared to OVX rats.

\section{Serum calcitonin and PTH levels}

Serum calcitonin level of OVX rats was decreased significantly $(P<0.05)$, in comparison with rats of the sham group. Concerning serum PTH, OVX rats showed a significant increase $(P<0.05)$ in their concentration, as compared with the sham group. Interesting enough, administration of CES powder restored significantly $(\mathrm{P}<$ $0.05)$ the serum calcitonin and PTH levels near to its normal value (Table 5). On the other hand, administration of alendronate drug caused a significant decrease $(\mathrm{P}<$
0.05) only in the PTH level, as compared with OVX group (Table 5).

\section{Bone oxidative stress markers}

Table 6 shows a significant increase $(P<0.05)$ in the level of bone MDA in OVX rats, as compared to rats of the sham group. Administration of CES powder or alendronate ameliorated the abnormal effects caused by ovariectomy, since a significant decrease $(P<0.05)$ in MDA levels were recorded. GPx and SOD activities were significantly decreased $(P<0.05)$ in OVX rats in comparison with sham group. Interestingly, CES powder or alendronate treatment increase GPx and SOD activities significantly $(P<0.05)$, as compared to OVX rats (Table 6). TAC was significantly decreased $(P<$ 0.05 ) in the OVX rats, as compared to the sham rats. Meanwhile, CES powder supplementation caused pronounced increase in TAC level, as compared to OVX rats. However, treatment with alendronate caused a nonsignificant change concerning serum TAC level of rats, as compared to OVX rats (Table 6).

\section{DISCUSSION}

Osteoporosis is a metabolic bone disease which results from a disturbance in the normal bone remodeling, tilting the balance to bone resorption over formation. Low calcium diet leads to a decrease in calcium absorption and this may be the most important mechanism involved in bone loss in aging humans (Alevizaki et al., 1973). Therefore, calcium supplements are used for aiding treatment of osteoporosis and fracture prevention (Nordin, 1997).

Han et al. (2007) worked on Ostreae testa shell powder that contain inorganic calcium and proved that this powder prevents bone loss in OVX mice. The present work recorded that one of the main constituent of CES powder is calcium where it contains about $19.38 \%$ of inorganic calcium. Moreover, the current study revealed that CES powder contained several amino acids (cysteine, glutamic acid, glycine and methionine). It was 
Table 6. Effect of CES on bone oxidative marker and antioxidant enzymes activity of rats.

\begin{tabular}{lcccc}
\hline Group & $\begin{array}{c}\text { MDA } \\
\text { (nM/mg protein) }\end{array}$ & $\begin{array}{c}\text { GPx } \\
\text { (mU/mg protein) }\end{array}$ & $\begin{array}{c}\text { SOD } \\
\text { (U/mg protein) }\end{array}$ & $\begin{array}{c}\text { TAC } \\
\text { (nM/mg protein) }\end{array}$ \\
\hline Sham & $0.190 \pm 0.029^{\mathrm{a}}$ & $13.832 \pm 1.586^{\mathrm{a}}$ & $22.443 \pm 1.011^{\mathrm{ac}}$ & $69.71 \pm 5.24^{\mathrm{a}}$ \\
OVX & $0.458 \pm 0.008^{\mathrm{b}}$ & $5.622 \pm 0.828^{\mathrm{b}}$ & $10.846 \pm 0.547^{\mathrm{b}}$ & $32.89 \pm 4.68^{\mathrm{b}}$ \\
OVX+CES & $0.35 \pm 0.031^{\mathrm{c}}$ & $15.226 \pm 0.916^{\mathrm{a}}$ & $23.161 \pm 1.82^{\mathrm{c}}$ & $74.36 \pm 4.69^{\mathrm{a}}$ \\
OVX+Alendronate & $0.333 \pm 0.013^{\mathrm{c}}$ & $16.804 \pm 2.041^{\mathrm{a}}$ & $20.636 \pm 1.183^{\mathrm{ac}}$ & $47.32 \pm 6.05^{\mathrm{c}}$ \\
\hline
\end{tabular}

All values are means \pm SE $(n=7)$. Values with different superscript letters are significantly different $(P<0.05)$.

reported that these amino acids reduce lipid peroxidation, protect membrane damage and restore the changes of the glutathione system (Slyshenkov et al., 2002). Furthermore, the CES powder showed a unique scavenging activity by reacting with DPPH and therefore it could be considered as one of the natural antioxidants. The present acute toxicity study revealed that the $\mathrm{LD}_{50}$ of CES powder is in excess of $5,000 \mathrm{mg} / \mathrm{kg}$. This finding represents an indication of CES powder safety. On the other hand, alendronate as many drugs has several adverse effects (Kuehn, 2009).

Measurement of BMD of bone provided good predictable information about efficacy of anti-osteoporotic agents (Diez, 2002). The current study manifested that OVX significantly decreased the BMD and the BMC of the total tibia when compared with the control group and this indicated that tibial bone loss had occurred. Picherit et al. (2000) reported that the decrease in BMD and BMC may attribute to increased bone turnover and/or disturbance in calcium homeostasis in ovariectomized rats. In addition, Sontakke and Tare (2002) reported that an increase in superoxide formation by the osteoclasts is often accompanied with active bone resorption and loss of bone density. The present study demonstrated that calcium supplementation when combined with ovariectomy had reverse the influence on tibial bone loss and this finding is in consistence with the observation of Zhang et al. (2006) who worked on Lepidium meyenii. CES powder may increase the BMD as it contains the major mineral elements such as calcium and phosphorus which are necessary to bone building. Also, CES powder could reduce bone loss by stimulating the antioxidant defense system and enhance the antioxidant status, this explanation is supported by the view of Pasco et al. (2006).

Calcium was found to be a significant predictor of BMD change (Macdonald et al., 2004). The ongoing study found that ovariectomy led to a significant hypocalcemia in the serum and bone of rats and this result was found to be in consistence with Zhang et al. (2006). Again, Burali et al. (2010) reported that ovariectomy resulted in an impaired calcium balance which could also have contributed to demineralization and eventually development of postmenopausal osteoporosis. Katz and Weinerman (2010) added that osteoclast cells secrete both hydrogen ions (resorb the mineral component) and proteases (digest the protein matrix) and these explanations interpret the decreased levels of $\mathrm{Ca}, \mathrm{P}$ and ALP in bone in the current study. The decreased levels of $\mathrm{Ca}$ and $\mathrm{P}$ caused by ovariectomy were ameliorated in CES group better than alendronate group and this is in agreement with Prabhakara and Lakshmana (2003) who worked on herbomineral preparation (OST-6). This improvement may be due to an increased calcium uptake from the CES powder administration. The present finding of bone $\mathrm{Ca}$ and $\mathrm{P}$ contents support the observations concerning the BMD and BMC of the different experimental groups.

ALP is considered as one of key enzymes for bone calcification which provides an index of bone formation (Squadrito et al., 2002). In fact, the total ALP (TALP) level in serum is less sensitive as a bone formation marker, since the present levels of serum TALP showed an insignificant difference between the different experimental groups. Whyte (1994) reported that bone ALP, which is produced by immature osteoblasts, play an essential role in the initiation of bone mineralization and is a more specific marker of bone formation. Concerning bone ALP (BALP), the present result showed that OVX decreased the activity of ALP in bone tissue and this was found in consistent with Raisz (1997). He mentioned that a characteristic decline in the BALP associated with postmenopausal women is due to disturbance in osteoblast function. The decreased level of BALP was ameliorated by CES powder treatment better than alendronate treatment. This may indicate a positive effect on osteoblast differentiation, particularly bone mineralization (Mori-Okamoto et al., 2004) and a higher osteoblast activity account for bone formation which in turn prevents osteoporosis (Omara et al., 2009).

Consequently, the current study demonstrated the beneficial effect of CES powder on osteoblastic cells and bone formation. Furthermore, the increased level of BALP in CES treated group may be attributed to the increased levels of $\mathrm{Ca}$ and $\mathrm{P}$ contents in bone (Buckwalter and Cooper, 1987). Debernard et al. (1986) reported that BALP could act as a plasma membrane transporter for inorganic phosphate, or an extracellular calcium-binding protein that stimulates calcium phosphate precipitation and orients mineral deposition into osteoid. BALP may also be involved in the mineralization process by hydrolyzing 
organic phosphates to release free inorganic phosphorus at sites of mineralization (Mori-Okamoto et al., 2004).

The present results revealed a significant elevation in PTH level and a significant reduction in calcitonin level in OVX rats and these results are consistent with Shalaby et al. (2011). Riggs and Melton (1986) attribute the hyperparathyroidism in osteoporotic rats to calcium deficiency and exacerbated by estrogen deficiency. The principal role of PTH lies in its responsibility for the minute-to-minute regulation of calcium levels in the blood and extracellular fluid. Furthermore, the PTH and calcitonin levels were reversed in CES treated group, as compared to OVX group. CES powder may exert its effect by increasing calcitonin level, which plays a major role in $\mathrm{Ca}$ homeostasis by inhibiting osteoclast-mediated bone resorption through the regulation of both the number and activity of osteoclasts (Karsdal et al., 2008). The DEXA measurements together with increased levels of bone forming markers indicate that the incorporation of minerals into bone matrix was enhanced in CES supplement. This indicates that the shell powder could be effective for bone formation.

Recently, various evidences were linked bone loss to ROS (Yalin et al., 2012). MDA is one of the main products of lipid oxidation and it has been widely used as an index of lipid peroxidation (Suttnar et al., 2001). The current investigation showed a relation between osteoporosis and ROS generation, since the OVX rats showed a significant elevation of MDA level and significant decrease of GPx, SOD and TAC activities. These results are in agreement with Sontakke and Tare (2002) and Ozgocmen et al. (2007). Yalin et al. (2005) illustrated that SOD, CAT and GPx are the major enzymatic antioxidants involved in the protection against $\mathrm{O}_{2} \bullet-$ and $\mathrm{H}_{2} \mathrm{O}_{2}$. Interestingly, these effects were reversed in rats treated with CES powder. In contrast, alendronate induces oxidative stress in the liver of ovariectomized rats (Yalin et al., 2010). In addition, the present results indicate that non-significant change was recorded in TAC level after alendronate treatment in comparison to OVX group. The protective effect that appears after the treatment of OVX rats with CES powder may be due to osteoblast activation which produces antioxidants such as GPx to protect against oxidative damage and this expectation was supported by Dreher et al. (1998). Furthermore, the protective efficacy of CES powder may be due to its antioxidant activity. Basu et al. (2001) reported that antioxidants scavenge free radicals and have been shown to inhibit bone resorption and stimulate bone formation.

The scanning electron microscope (SEM) images of femur add a confirmatory note to the findings of all biochemical analysis. Again, the high rate of bone turnover was well corrected by CES powder, suggesting that CES may have protective action against ovarian hormone insufficiency-related bone resorption, this is in agree with the explanation of Burali et al. (2010).

\section{Conclusion}

CES powder is considered an attractive candidate for developing a potential therapeutic agent and a cheap alternative for postmenopausal osteoporosis treatment. However, much detailed investigation has to be undertaken in this regard to validate the use of CES powder in postmenopausal osteoporotic women condition.

\section{ACKNOWLEDGEMENT}

A special thanks to Dr. Kareem Said Morsy, a lecturer of parasitology, Zoology Department, Faculty of Science, Cairo University, for his assistance in constructing photos.

\section{REFERENCES}

Alevizaki C, lkkos D, Singhelakis P (1973). Progressive decrease of true intestinal calcium absorption with age in normal man. J. Nucl. Med. 14:760-762.

Basu S, Michaelsson K, Olofsson H, Johansson S, Melhus H (2001). Association between oxidative stress and bone mineral density. Biochem. Biophys. Res. Commun. 288:275-279.

Belfield A, Goldberg DM (1971). Revised issue for serum phenyl phosphatase activity using 4-amino-antipyrine. Enzyme 12:561.

Brand WW, Cuvelier HE, Berset C (1995). Use of a free radical method to evaluate antioxidant activity. Food Sci. Technol. 82:25-30.

Buckwalter JA, Cooper RR (1987). The cell and matrices of skeletal connective tissue. In: Albright JA, Brand RA (eds.) The Scientific Basis of Orthopedics, 2nd ed. Appleton \& Lange, Norwalk, CT, USA. pp. 1-29.

Burali SC, Kangralkar V, Sravani OS, Patil SL (2010). The beneficial effect of ethanolic extract of Moringaoleifera on osteoporosis. Int. J. Pharm. Appl. 1:50-58.

Debernard B, Bianco P, Bonucci E, Costantini M, Lunazzi GC, Martinuzzi P (1986). Biochemical and immunohistochemical evidence that in cartilage an alkaline-phosphatase is a Ca2+-binding glycoprotein. J. Cell Biol. 103:1615-1623.

Diez F (2002). Guidelines for the diagnosis of osteoporosis by densitometric methods. J. Manip. Physiol. Ther. 25:403-415.

Dreher I, Schütze N, Baur A, Hesse K, Schneider D, Köhrle J,Jakob F (1998). Selenoproteins are expressed in fetal human osteoblast-like cells. Biochem. Biophys. Res. Commun. 245:101-107.

El-Merzabani MM, El-Aaser AA, Zakhary NI (1977). A new method for determination of inorganic phosphorus in serum without deprotinization. J. Clin. Chem. Clin. Biochem. 15:715-718.

Fraser JHE, Helfrich MH, Wallace HM, Ralston SH (1996). Hydrogen peroxide, but not superoxide, stimulates bone resorption in mouse calvariae. Bone 19(3):223-226.

Frost HM, Jee WS (1992). On the rat model of human osteopenias and osteoporoses. Bone Miner. 18:227-236.

Gindler M, King JD (1972). Chemical method for determination of calcium in serum. Am. J. Clin. Pathol. 58:376.

Han SY, Lee HR, Kwon YK, Jo MJ, Park SJ, Kim SC, Lee HS, Ku SK (2007). Ostreaetestae preventovariectomy-induced bone loss in mice by osteoblast activations. J. Ethnopharmacol. 114:400-405.

Heaney R (1996). Nutrition and risk for osteoporosis. In: Marcus R, Feldman D, Kelsey J (eds.), Osteoporosis. San Diego, CA: Academic Press Inc. pp. 498-499.

Jo $\mathrm{H}$, Choi M (2008). Effects of isoflavone supplementation on the bone mineral density of growing female rats. Nutr. Res. Pract. 2:68-73.

Kanis JA, McCloskey EV, Johansson H, Oden A, Melton JM III, Khaltaev A (2008). A reference standard for the description of 
osteoporosis. Bone. 42:467-475.

Kaplan B, Hirsch M (2004). Current approach to fracture prevention in postmenopausal osteoporosis. Clin. Exp. Obstet. Gynecol. 31:251255.

Karsdal MA, Henriksen K, Arnold M, Christiansen C (2008). Calcitonin: a drug of the past or for the future? Physiologic inhibition of bone resorption while sustaining osteoclast numbers improves bone quality. Biol. Drugs 22:137-144.

Katz S, Weinerman S (2010). Osteoporosis and gastrointestinal disease.Gastroenterol. Hepatol. 6:506-517.

Koracevic D, Koracevic G, Djordjevic V, Andrejevic S, Cosic V (2001).Method for the measurement of antioxidant activity in human fluids. J. Clin. Pathol. 54:356-361.

Kuehn BM (2009). Long-term risks of bisphosphonates probed. J. Am. Assoc. 301:710-711.

Kupferer EM, Dormire SL, Becker H (2009). Complementary and alternative medicine use for vasomotor symptoms among women who have discontinued hormone therapy. J. Obstet. Gynecol. Neonatal Nurs. 38:50-59.

Lean JM, Jagger CJ, Kirstein B, Fuller K, Chambers TJ(2005). Hydrogen peroxide is essential for estrogen-deficiency bone loss and osteoclast formation. Endocrinol. 146(2):728-735.

Macdonald HM, New SA, Golden MHN, Campbell MK, Reid DM (2004).Nutritional associations with bone loss during the menopausal transition: evidence of a beneficial effect of calcium, alcohol, and fruit and vegetable nutrients and of a detrimental effect of fatty acids. Am. J. Clin. Nutr. 79:155-165.

Miller SC, Bowman BM (1998). Comparison of bone loss during normal lactation with estrogen deficiency osteopenia and immobilization osteopenia in the rat. Anat. Rec. 251:265-274.

Moloukhia H, Sleem S (2011). Bioaccumulation, Fate and Toxicity of Two Heavy Metals Common in Industrial Wastes in Two Aquatic Molluscs. J. Am. Sci. 7:459-464.

Mori-Okamoto J, Otawara-Hamamoto $\mathrm{Y}$, Yamato $\mathrm{H}$,Yoshimura M (2004). Pomegranate extract improves a depressive state and bone properties in menopausal syndrome model ovariectomized mice. J. Ethnopharmacol. 92:93-101.

Nishikimi M, Appaji N, Yagi K (1972). The occurrence of superoxide anion in the reaction of reduced phenazinemethosulfate and molecular oxygen. Biochem. Bioph. Res. Common. 46:849-854.

Nordin BEC (1997). Calcium and osteoporosis. Nutrition 13:664-686.

OECD (2001). OECD Guideline 425: Acute Oral Toxicity-Up-and-Down Procedure. In: OECD Guidelines for the Testing of Chemicals Vol.2 Organization for Economic Cooperation and Development. Paris, France.

Ohkawa H, Ohishi N, Yagi K (1979). Assay for lipid peroxides in animal tissues by thiobarbituric acid reaction. Anal. Biochem. 95:51-358.

Omara EA, Shaffie NM, Et-Toumy SA, Aal WA (2009). Histomorphometric Evaluation of Bone Tissue Exposed to Experimental Osteoporosis and Treated with RetamaRaetam Extract. J. App. Sci. Res. 5:706-716.

Ozgocmen S, Kaya H, Fadillioglu E, Yilmaz Z (2007). Effects of calcitonin, risedronate, and raloxifene on erythrocyte antioxidant enzyme activity, lipid peroxidation, and nitric oxide in postmenopausal osteoporosis. Arch. Med. Res. 38:196-205.

Paglia DE, Valentine WN (1967). Studies on the quantitative and qualitative characterization of erythrocyte glutathione peroxidase. J. Lab. Clin. Med. 70:158-169.

Parhizkar S, Ibrahim R, Latiff LA (2008). Incision choice in laparatomy: a comparison of two incision techniques in ovariectomy of rats. World Apple Sci. J. 4:537-540.

Pasco JA, Henry MJ, Wilkinson LK, Nicholson GC, Schneider HG, Kotowicz MA (2006). Antioxidant vitamin supplements and markers of bone turnover in a community sample of nonsmoking women. J. Womens Health (Larchmt). 15(3):295-300.

Pérez Llamas F, GarauletAza M, Gil Hernndez A, Zamora Navarro S (2010). Calcio, fosforo, magnesio y floor.MetabolismoOseo y suregulacion, In: Tratado de Nutricion, A. Gil Hernndez, (Ed.), Editorial Médica Panamericana, Madrid, Spain. pp. 897-925.

Peterlik M, Kállay E, Cross H S (2013). Calcium nutrition and extracellular calcium sensing: Relevance for the pathogenesis of osteoporosis, cancer and cardiovascular diseases. Nutrition 5:302327.

Picherit C, Coxam V, Bennetau-Pelissero C, Kati-Coulibaly S, Davicco MJ, Lebecque P, Barlet JP (2000). Daidzein Is More Efficient than Genistein in Preventing Ovariectomy-Induced Bone Loss in Rats Biochemical and Molecular Action of Nutrients. J. Nutr. 130:16751681.

Prabhakara RN, Lakshmana M (2003). Prevention of bone loss in calcium deficient ovariectomized rats by OST-6, a herbal preparation. J. Ethnopharmacol. 84:259-264.

Radwan NM, Ahmed NA, AboulEzz HS (2007). Disturbances in amino acid neurotransmitters induced by mobile phone radiation in the hypothalamus of young and albino rats. J. Union Arab Biol. 27:73-91.

Raisz LG (1997). The osteoporosis revolution. Ann. Intern. Med. 126:458-462.

Ramajayam G, Sridhar M, Karthikeyan S, Lavanya R, Veni S, Vignesh RC, llangovan R, Djody SS, Gopalakrishnan V, Arunakaran J (2007). Effects of Aroclor 1254 on femoral bone metabolism in adult male Wistar rats. Toxicol. 241:99-105.

Riggs BL, Melton LJ (1986). Involutional osteoporosis. N. Engl. J. Med. 314:1676-1686.

Rosenberg SV, Wehr U, Bachmann H (2007). Effect of vitamin Dcontaining plant extracts on osteoporotic bone. J. Steroid Biochem. Mol. Biol. 103:596-600.

Sánchez-Rodríguez MA, Ruiz-Ramos M, Correa-Muñoz E, MendozaNúñez VM (2007). Oxidative stress as a risk factor for osteoporosis in elderly Mexicans as characterized by antioxidant enzymes. BMC Musculoskelet. Disord. 8:124-130.

Shaker SM, Mohamed GF, Saleh HAA (2005).Histological study on the effect of calcium supplementation in prophylaxis and treatment of osteoporosis in ovariectomized rats. Egypt. J. Histol. 28:191-198.

Shalaby NMM, Abd-Alla HI, Ahmed HH, Basoudan N (2011). Protective effect of Citrus sinensis and Citrus aurantifolia against osteoporosis and their phytochemical constituents. J. Med. Plants Res. 5:579-588.

Shirke SS, Jadhav SR, Jagtap AG (2008). Methanolic extract of Cuminum cyminum inhibits ovariectomy induced bone loss in rats. Exp. Biol. Med. 233(11):1403-1410.

Slyshenkov VS, Shevalye AA, Liopo AV, Wojtczak L (2002). Protective role of $L$ methionine against free radical damage of rat brain synaptosomes. Acta Biochim. Polym. 49:907-916.

Sontakke AN, Tare RS (2002). A duality in the roles of reactive oxygen species with respect to bone metabolism. Clin. Chim. Acta 318:145148.

Squadrito F, Altavilla D, Squadrito G, Saitta A, Cucinotta D, Minutoli L,Deodato B, Ferlito M, Campo GM, Bova A, Caputi AP (2002). Genistein supplementation and estrogen replacement therapy improve endothelial dysfunction induced by ovariectomy in rats. Cardiovasc. Res. 45:454-462.

Stagos D, Amoutzias GD, Matakos A, Spyrou A, Tsatsakis AM, Kouretas D (2012). Chemoprevention of liver cancer by plant polyphenols. Food Chem. Toxicol. 50:2155-2170.

Suttnar J, Másová L, Dyr JE (2001). Influence of citrate and EDTA anticoagulants on plasmamalondialdehydeconcentrations estimated by high-performance liquid chromatography. J. Chromatogr. B. Biomed. Sci. Appl. 751:193-197.

Swaminathan R (2001). Biochemical markers of bone turnover. Clin. Chim. Acta 313:95-105.

Teófilo JM, Azevedo ACB, Petenusci SO, Mazaro R, Lamano-Carvalho TL (2003). Comparison between two experimental protocols to promote osteoporosis in the maxilla and proximal tibia of female rats. Pesqui. Odontol. Bras. 17:302-306.

Tiegs RD, Body JJ, Barta JM, Heath H (1986).Secretion and metabolism of monomeric human calcitonin: effects of age, sex, and thyroid damage. J. Bone Miner. Res. 1:339-349.

Wadolowska L, Sobas K, Szczepanska J W, Slowinska M A, CzlapkaMatyasik M, Niedzwiedzka E (2013). Dairy Products, Dietary Calcium and Bone Health: Possibility of Prevention of Osteoporosis in Women: The Polish Experience. Nutr. 5:2684-2707.

Wallace L, Boxall M, Riddick N (2004).Influencing exercise and diet to prevent osteoporosis: lessons from three studies. Br. J. Commun. Nurs. 9:102-109. 
Weitzmann MN, Pacifici R (2006). Estrogen deficiency and bone loss: An inflammatory tale. J. Clin. Investig. 116:1186-1194.

Whyte MP (1994). Hypophosphatasia and the role of alkaline phosphatase in skeletal mineralization. Endocrine Rev. 15:439-461.

Yalin S, Bagis S, Polat G (2005). Is there a role of free oxygen radicals in primary male osteoporosis? Clin. Exp. Rheumatol. 23:689-692.

Yalin S, Çömelekoğlu Ü, Bağiş S, Berköz M, Eroğlu P (2010). Effects of alendronate and risedronate therapy on hepatic antioxidant enzyme activity and lipid peroxidation in ovariectomized rats. Turk. J. Med. Sci. 40:613-618.
Yalin S, Sagír O, Comelekoglu U, Berköz M, Eroglu P (2012). Strontium ranelate treatment improves oxidative damage in osteoporotic rat model. Pharmacol. Rep. 64(2):396-402.

Zhang Y, Longjiang YU, Mingzhang AO, Wenwen JIN (2006). Effect of ethanol extract of LepidiummeyeniWalp. on osteoporosis in ovariectomized rat. J. Ethnopharmacol. 105:274-279. 